\title{
Mechanomics and Physicomics in Gravisensing
}

\author{
Jack J. W. A. van Loon
}

Received: 15 October 2007 / Accepted: 15 April 2008 / Published online: 3 September 2008

(C) The Author(s) 2008. This article is published with open access at Springerlink.com

\begin{abstract}
Sensing gravity by 'non-specialized' cells is still puzzling. We don't know where or by which mechanism such cells sense gravity. These questions in 'gravisensing' are not much different from questions in general mechanobiology. Numerous studies have been reported in this field in the last couple of decades. What are the mechanical properties of a cell? Are there differences in mechanical properties between cell types and if so why? How are forces perceived and transduced to a meaningful biological event. Novel techniques such as optical and magnetic tweezers, atomic force microscopy, magnetophoresis and computer modeling make the field of mechanosensing or perhaps physicomics accessible. A similar approach should also be applied for gravity-related research. This paper addresses the current techniques used in mechanosensing and exemplifies how a cell could sense the relatively weak force of gravity.
\end{abstract}

Keywords Gravity • Microgravity • Weightlessness • Physicomics - Mechanotransduction - Conformational change $\cdot$ Space flight $\cdot$ Cell mechanics $\cdot$ Mechanomics . Mechanobiology

\footnotetext{
J. J. W. A. van Loon ( $\varangle)$

Dutch Experiment Support Center (DESC),

Department of Oral Cell Biology, ACTA, Vrije Universiteit,

van der Boechorststraat 7, 1081 BT Amsterdam,

The Netherlands

e-mail: j.vanloon@vumc.nl

URL: www.desc.med.vu.nl
}

\section{Introduction}

At a (sub) cellular level the force of gravity is insignificant compared to the three other basic forces in nature; the weak nuclear force, the strong nuclear force and the electrostatic force, that govern the force field within and between molecules inside a cell. Non-gravity related phenomena like thermal noise $(\mathrm{kT})$ or chemical energies are orders of magnitude larger than $1 \times \mathrm{g}$ acceleration (Albrecht-Buehler 1991). However, the main difference between a gravitational load and phenomena like Brownian motion is that gravity is continuously acting in the same direction. Over the last decades space flight provided the opportunity to perform microgravity experiments, and a good body of knowledge provides compelling evidence that this seemingly weak force directly impacts single cells as described by Mesland and Brillouet (1987), Brillouet (1995), Demets (1996), Moore and Cogoli (1996), Brinckmann and Brillouet (1999), Gaubert et al. (1999), Cogoli (2002), Clément and Slenzka (2006), Häder et al. (2006) and Brinckmann (2007). However, it is still unclear how this force impacts especially 'non-professional' cells, i.e. cells that would not seem to require a gravity sensor for proper functioning in contrast to 'professional' gravisensing cells such as plant columella cells or specialized single cells in vestibular systems.

Gravitational biology overlaps with or is part of mechanobiology. In mechanobiology we try to understand the impact of forces on whole systems, single cells, sub-cellular structures or even individual molecules. In gravitational biology studies we should distinguish experiments that study direct and indirect gravity effects on cells like the lack of convection under true weightlessness; see also Klaus (2001), Thevenet et al. 


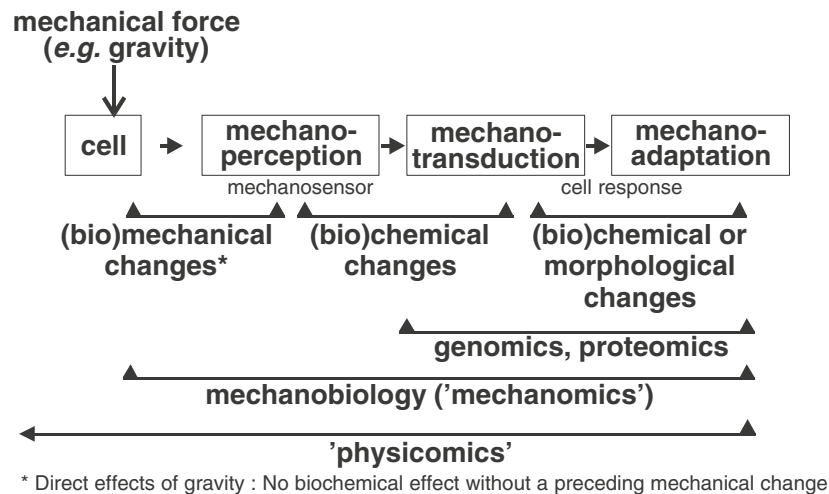

Fig. 1 Terminology and sequence of events in cell biomechanics. In mechanobiology we study effects of mechanical forces within and/or applied to a cell or parts of it, this can be termed as mechanomics. Extending this to the overall physical environment and processes around and within a cell we might even use the term 'physicomics'

(1996) and Brown et al. (2002). The focus of this paper is on direct effects of gravity onto cells.

In mechano- or gravitational biological experiments we apply or remove a mechanical force to change something in the cellular machinery to learn about underlying, general, biological mechanisms. The force evokes changes in the cell that lead to either damage or adaptations of the cell, which can be divided into several steps. First we have mechanoperception to detect a change in the mechanical forces acting upon a cell, presumably through sensors. The sensor's signal is relayed, or transduced, to a cellular response that elicits a response and or leads to mechano-adaptation (see Fig. 1). My hypothesis is that all reported changes in ion fluxes, protein levels and phosphorylation, changes in potentials, signaling molecules levels, or any biochemical changes are provoked by a mechanical modification somewhere within the cell or on its membrane. There are no biochemical modifications without prior mechanical change. Somehow cells within e.g. bone detect their mechanical usage, including weight, and adapts its structure accordingly. Similar processes occur in other systems like plants.

\section{Instruments and Methods to Study (Sub-) Cellular and Molecular Mechanics}

In the more distant past, mechano-biological studies were generally performed on tissue level like whole muscle groups or single bones. Recently we see a shift towards smaller entities like single cells or even individual molecules. Various instruments and techniques have been developed to study cellular mechanics.
Although not extensive, we shall address some of the most common technologies used to qualify and quantify cell mechanical properties (see Fig. 2).

Cole published one of the first papers on the practical use of the voltage clamp better known as the patch clamp technique (Cole 1949). In short, a small pipette is filled with suitable solutions. A metal electrode in the solution conducts electrical changes to a voltage clamp amplifier. In this way the transport of ion through individual ion channels in the membrane can be monitored. Although this technique is not used to directly measure cell mechanical properties several studies have shown mechanosensitive ion channels like the one for calcium (Autret et al. 2005).

Later, similar pipettes were used for a membrane aspiration technique developed by Mitchison and Swann (1954) in the early 1950s, in which forces are applied on the cell or vacuole membrane in order to deform them.

One of the earlier studies directly measuring whole single cell mechanical parameters were performed by McConnaughey and Petersen (1980) in the early nineteen eighties using a cell poker. In these 'cytotensiometric' measurements using attached mouse $3 \mathrm{~T} 3$ fibroblasts they were able to apply a force of $10 \mu \mathrm{N}\left(10^{-3}\right.$ dyne $)$. Current developments lower the applied force to few picoNewton $(\mathrm{pN})$.

Coated magnetic beads can be firmly attached to a cell surface. Applying a directed magnetic field to such a system forces the beads to rotate and thus apply a mechanical stress onto that part of the cell surface. Wang and coworkers introduced this technique in 1993 (Wang et al. 1993).

Fig. 2 Cartoons for the various tools and techniques used in mechano-biology. a Membrane aspiration. b Cell poking or membrane indentation. See also for a recent example of a cell poking study the paper by Geitmann (2007) in this same ASGSB Bulletin issue. c Application of magnetic beads attached to a cell surface. d Representation of a standard optical tweezer setup. The beads are trapped with two laser beams. A polymer, like DNA, or a complete cell may be attached between to the beads. By shifting the path of the lasers one can move the beads and apply a force to the interconnecting object. e Representation of a particle tracking set-up where stained particles within a cell can be monitored using a regular light or fluorescent microscope. f A squeezing plate or probe. The upper plate can move carefully towards an attached cell. g An AFM set-up. The cell surface is probed with a tip fixed to a constantly vibrating cantilever. Both height and force can be measured. h Surface stretch/deformation experiment. Studies are most often performed applying a unidirection or omni-directional stress. i Simple representation of a gravity force acting upon a monolayer of cells. See for an overview of gravity related ground facilities van Loon et al. (1999). j Simple representation of hydrostatic pressure acting upon a cell monolayer. $\mathbf{k}$ Fluid shear stress acting upon a cell monolayer. I Vibration acceleration in $\mathrm{X}-\mathrm{Y}$ direction applied onto a cell monolayer 


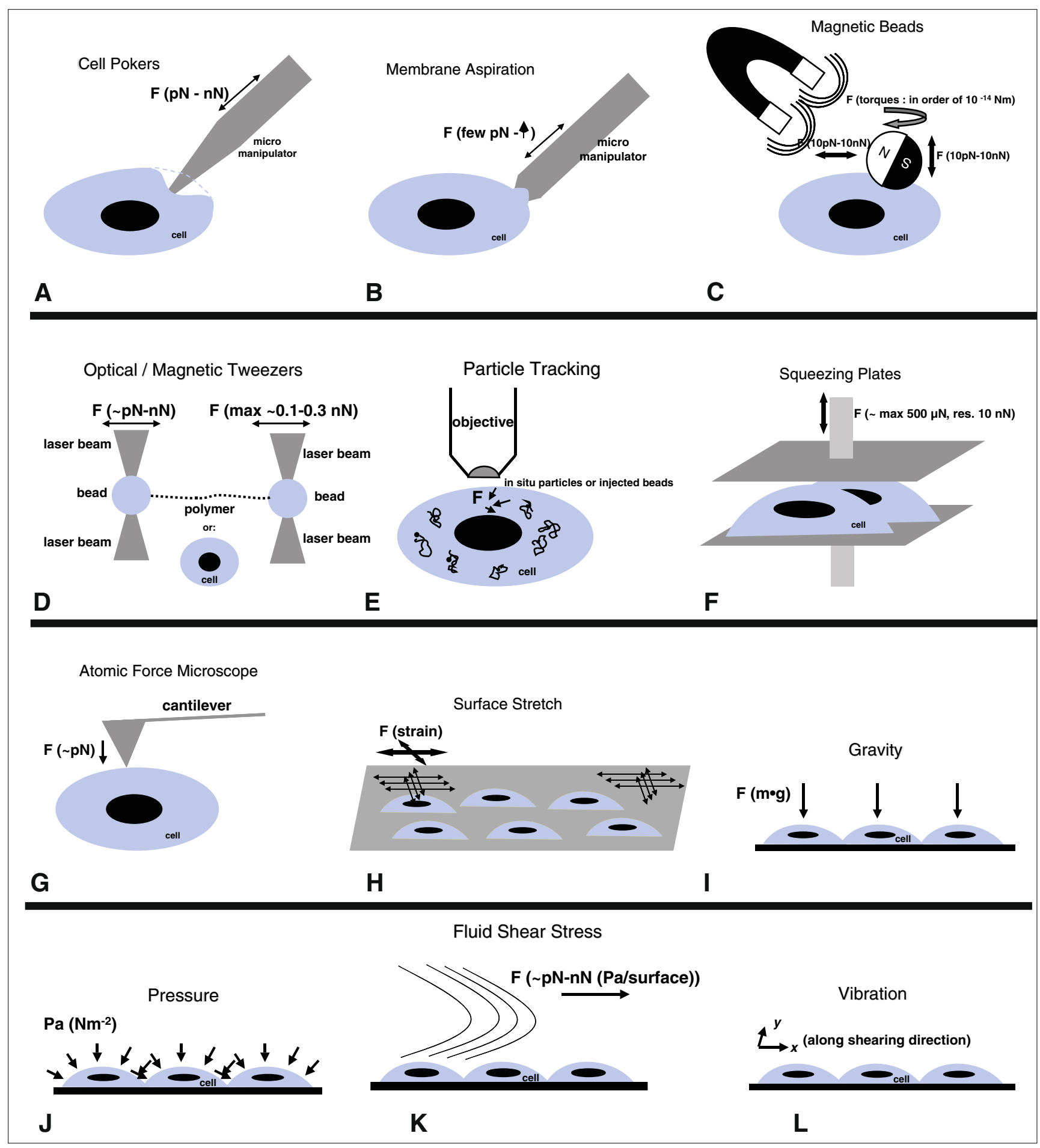

Optical tweezers utilize an optical field gradient to "trap" micron-sized refractive objects such as polystyrene beads. This trap can be controlled spatially in three dimensions. Single molecules can be attached to beads or to the cell surface, e.g., via integrins. The relation between the displacement and force (i.e. strain) provides information of the mechanical properties of the material. Sasaki et al. (1992) introduced the tech- nique in 1992 and the work of Ashkin (1997) promoted its application in biological studies. Magnetic beads were earlier applied in a magnetic tweezer set-up using a single DNA molecule by Smith et al. (1992).

Magnetic properties may also be applied to study cell mechanical properties. Kuznetsov and Hasenstein (1997) applied a ferromagnetic wedge to generate a high gradient magnetic field to dislocate amyloplasts 
in barley coleoptiles and tomato hypocotyls. High gradient magnetic fields can be applied at a larger scale, i.e. to whole organisms for example in a sufficiently large bore of a Bitter magnet. Berry and Geim (1997) demonstrated the levitation of various biological organisms including a living frog. The authors postulated that magnetic levitation might be seen as possible microgravity simulations for biological samples. However, a distinction has to be made between compensating weight and other phenomena such as convection, as compared to real microgravity (Poodt et al. 2005) especially for inhomogeneous biological samples.

Besides using external forces, we may also use straightforward observation to track intracellular components. Molenaar et al. (2003) used fluorescentlytagged beads coupled to telomeric complexes to study the dynamic behavior of the telomeric DNA in osteosarcoma cells. Tseng et al. (2002) made use of the inherent Brownian motion of microinjected fluorescent particles in a live-cell multiple-particle-tracking microrheology technique. They showed that the cytoplasm is much more mechanically heterogeneous than relatively simple reconstituted actin filament networks.

With a micro-squeezing plate it is possible to apply static or dynamic loads up to about $500 \mu \mathrm{N}$ with a resolution of $10 \mu \mathrm{N}$ on individual cells, measuring the resulting forces while observing the cell with a confocal microscope (Peeters et al. 2003). The device is specifically developed to study the cellular background mechanisms for pressure sores.

A fairly commonly used device in biomechanics is the atomic force microscope, AFM. With the advent of the AFM (Binnig et al. 1986) resolution on the nanometer scale has become possible and its ability to manipulate objects is a significant improvement over light microscopy. In many ways this method is related to cell poking, but it has better spatial and force resolution. The obvious limitation of the technique is that manipulation can only occur through the accessible surface of a cell, i.e. one cannot measure elastic moduli inside the cell without an influence of boundary conditions. Recently, AFM has been used in combination with gravity loading (van Loon et al. 2008).

One often-used paradigm on whole cell monolayers is surface stretch. A monolayer of cells is grown on a flexible membrane that is stretched or otherwise deformed to apply a mechanical stress via the substrate to the cells. Murray and Rushton (1990) developed one of the first systems of this kind used in bone biology using mouse calvariae cells studying PGE2 release. Gilchrist and colleagues (Gilchrist et al. 2007) studied individual cells using a micrometer device providing a uniaxial stretch to a cell-seeded substrate.

We can also use gravity as one of the environmental parameters to study basic processes in life. However, the focus in gravitational biology has long been, and maybe still is, the actual space flight, microgravity or better microweight experiments. If we want to study the impact of weight onto systems, it is as important to go into orbital space flight, as it is relevant to use centrifuges. Although physical processes, and therefore biological systems, are behaving differently under (near) weightlessness (Albrecht-Buehler 1991; Todd 1989; van Loon 2007c) including studies under hypergravity c.q. hyper-weight conditions provide information for the entire gravity spectrum (Hatton et al. 2003; Hemmersbach and Haeder 1999; Thoumine et al. 1996; Searby et al. 2005; Tabony 2004; van Loon et al. 1999). It was at first argued from a purely physical point of view, that non-specialized single cells might not be susceptible to small forces such as gravity (Pollard 1965; Went 1968), many studies have shown otherwise. In an experiment using an AFM within a large-radius centrifuge we were able to monitor shape changes of the same cell going from 1 to $3 \times \mathrm{g}$ (van Loon et al. 2008). Not only hypergravity centrifuges but also microgravity simulators such as clinostats or random positioning machines (RPM) are very useful tools in this respect (Klaus 2001; Briegleb 1965, 1967, 1992; Galland et al. 2004; van Loon 2007a).

Another paradigm to study cell mechanical properties is by the application of hydrostatic pressure. This has also been used quite frequently in studies on cell mechanics in the plant and animal kingdom in cell turgor (Geitmann 2007) or bone/cartilage research, respectively (Veldhuijzen et al. 1979; Klein-Nulend et al. 1987). In a more recent study by Kim and coworkers (Kim et al. 2007) hydrostatic pressure was used to study signal transduction pathways and mechano-transducers in mesenchymal stem cells. They showed that cyclic hydrostatic pressure enhances osteogenesis in a 3D culture system via ERK1/2 activation.

Osmotic pressure also provides insight in cell mechanics and functioning. Chondrocytes exposed to a hypo-osmotic stress reveal a decrease in elastic moduli and apparent viscosity but changes were not apparent when cells were exposed to hyper-osmotic environment. Rapid changes in cortical actin were noted with hypo-osmotic stress (Guilak et al. 2002).

The study of the impact of fluid shear stress onto cells has emerged from studies on the vascular system. While the focus in earlier reports was on the interaction of white blood cells to a vessel wall (Schmid-Schoenbein et al. 1975), recent studies apply fluid shear to unravel 
signal transduction pathways in endothelial cells (Sun et al. 2007). It has been postulated that fluid shear might also regulate bone cell mechanics (Piekarski and Munro 1977; Cowin et al. 1991). Recent studies from our lab have shown that MC-3T3-E1 osteoblastic bone cells are particularly responsive to specific fluid shear stress rates (Bacabac et al. 2004).

In addition to the auditory and cochlear system vibrations play an important role in nature. Vibration at large frequency ranges are used by a variety of sensory systems, like the ear or the proprioceptive sensors in feet or jaws in order to locate pray or for communication (Hill 2001). However, vibrations may also be exogenously applied to generate a biological effect. Tanaka et al. (2003) applied Gaussian quasiwhite noise to stimulate bone formation. Stochastic noise experiments in our lab using frequencies between 5 and $100 \mathrm{~Hz}$ have shown that nitric oxide and prostaglandin E2 production respond at specific frequencies. These effects might be due to nuclear motion within the cell during vibration (Bacabac et al. 2006). Naturally occurring vibrations due to Brownian motions can be used to estimate cell compliance as has been shown by Bacabac and colleagues (Bacabac 2006). Fitzgerald and Hughes-Fulford (1996) showed that the revere random vibrations during a Shuttle launch have a significant impact on gene expression in osteoblastic cells.

Also various configurations of cell culture micro patterned substrates are applied in relation to mechanobiology (Balaban et al. 2001). Lemmon and Romer (2007) started to use flexible rod shaped structures fixed onto a culture surface to which cells could attached. The rods would deflect in response to internal outwarddirected forces. Loesberg et al. $(2006,2007)$ used an isotropic microstructured surface in combination with hypergravity stress or simulated microgravity in a random positioning machine, RPM, to reveal the forces involved in cell orientation and morphology. Properties of standard plastic culture flasks are often taken for granted. Experiments are performed with regular tissue culture substrates, which is quite distant from the actual in situ mechanical environment that cells experience in vivo. Therefore cells are likely to incorporate such external conditions into their physiological response (Georges et al. 2004).

Finally, data emerging from biomechanical experiments of the sort mentioned above can be used to build a virtual cell. One can construct so-called finite element models, FEM, of a single cell or its components. Studies using these models can reveal interesting new insights into mechanical processes that later can be tested in vivo (Prendergast 2007).

\section{Discussion}

The last decade has seen a very fruitful contribution by physicists and engineers to biological questions such as in mechano-biology. In line with the terminology for DNA, RNA or protein research, genomics, transcriptomics and proteomics, respectively, we might use the term mechanomics to describe all the mechanical phenomena involved in cell physiology. This term was introduced by Sem et al. (2001). They used nuclear magnetic resonance, NMR technologies that characterize protein-ligand interactions combined with bioinformatics strategies across large families of proteins. The term "enzyme mechanomics" describes this newly enabled gene family wide characterization of structurefunction correlations but the term may be applied more widely. Mechanomics could include all mechanical interactions on the level of the cell, tissue and whole organism. On a cellular level, cytoskeleton elements are likely candidates for force generation and transduction processes. More intricate and possibly localized processes include the mechanical properties between the main cytoskeletal components and connections between the cytoskeleton and the cell membrane or cell wall. Mechanomics would also include molecular motors that use cytoskeletal structures such as myosins, dyneins, prestins or kinesins to facilitate intracellular transport and contractions. Processes like particle invagination, cell division, motility, cytoplasmatic streaming or particular ion channels are largely depending on mechanical or other physical processes. Therefore we should expand the term 'mechanomics' to include other physical parameters such as pressure, temperature, electro-magnetic fields et cetera and use a more comprehensive term of 'physicomics', which covers all physical properties involved in cell, tissue or body physiology. Characteristics and interactions of physical properties within a cell should be published similarly as in proteomics studies such as by Forgacs et al. (2004) on signaling networks and the cytoskeleton.

While the very first space biology experiments were quite basic and from the 'look-and-see' type, experimental facilities for gravitational biological studies have been improved over the years. However, current facilities and modules for space flight in vitro cell biology studies are still limited to the very basic 'rinse-andfix' type studies like in European facilities such as Biolab, Kubik or EMCS. Cells are cultured for some time, maybe some media changes are performed and finally stopped by chemical fixation. The nature of these experiments limits the assays mostly to mechanotransduction and mechano-adaptation but is less capable for studies on mechano-perception as shown in 
Fig. 1. Studying mechanosensing or gravisensing, especially in 'non-professional' cells, depends on flight facilities and the concepts and technology of the devices described here. If we want to unravel gravisensing we need to invest in more specific and sophisticated facilities capable of real time measurements such as confocal and near scanning field microscopes, atomic force microscopes and optical and magnetic tweezers. Such research facilities would cover a broad basis for cell biological research on the International Space Station, as initially promised for ISS and some suggested by the science community years ago (Goede et al. 1992; van Loon and van Hulst 1999). However, none of these capabilities have been realized up till now.

It seems that the hypothesis based on the various physical properties posed by Pollard (1965), Went (1968) or Albrecht-Buehler (1991) that the force of gravity is too small to provoke direct physiological responses effect on a single, non-professional cell is still valid. However, there are other examples in nature where the forces for mechanical loads onto a system, as measured or predicted in vivo, are too small to generate a biological response. It has been shown that bone cells do respond to fluid shear stress in vitro (Piekarski and Munro 1977) and that these shear forces may account for bone mechanoadaptation in vivo (Burger et al. 1998). However, the in vitro forces applied are much larger compared to predicted in vivo conditions. In an attempt to bridge this gap in understanding bone mechanoadaptation Han et al. (2004) postulated a 3D model to amplify the mechanical stress by about one order of magnitude. In the auditory system a model is proposed that amplifies the signal for high frequencies by hair bundles in the cochlea (Kennedy et al. 2005), while Brokaw postulated structural models that amplify the strain generated by motor enzymes (Brokaw 1997). Even relativistic models have been proposed to explain the way biological systems might amplify the impact of weak electromagnetic field onto cells (Saxena et al. 2003). So although gravity is a weak force on a cellular dimension similar amplification mechanisms as mentioned above might play a role in gravisensing, especially in non-professional cells.

The nature and localization of the mechano- or gravity sensor are key questions. Although this paper does not focus on the possible molecular candidates for this sensor, see for review by Hughes-Fulford (2004), as hypothesized, this molecule(s) should be able to go through some kind of conformational change. I it is likely to be found in the load-bearing regions of or near the focal adhesion complex and corresponding cytoskeletal connections as shown for cdc42 molecule (Xiang et al. 2006), vinculin (Balaban et al. 2001), fibronectin (Baneyx et al. 2001), angiostatin (Grandi et al. 2006) or PECAM-1 (Osawa et al. 2002). However, other regions within the cell should not be excluded nor the possibility that due to (micro-)gravity mobile parts within the fluidic membrane might be rearranged in such a way that different reaction kinetics might become apparent. The current assumption that many effects of (micro-)gravity on suspension cultures stem from the lack of convection in near weightlessness (Klaus 2001; Thevenet et al. 1996; Brown et al. 2002), this phenomenon could also apply to attached cells.

Gravity is a body force, so the whole cytosol might somehow be involved and this stress might be guided or concentrated to limited areas such as focal adhesions. It has been postulated that the small effect of gravity is integrated and/or amplified through mechanisms like reaction-diffusion (Turing 1952; Papaseit et al. 2000), stochastic resonance (Pierson and Moss 1995; Galvanovskis and Sandblom 1997; Greenwood et al. 2000; Hänggi 2002) or 'signal averaging' of a constant small stimulus (Kondepudi 1991).

Experiments applying mechanical forces like fluid shear stress or tethered beads exhibit a threshold value of $\sim 1 \mathrm{nN}$ per cell (Huang et al. 2004). The force to generate a conformational change in individual molecules like FAT-Paxillin is $125 \mathrm{pN}$ (Kamm and KaazempurMofrad 2004). The maximum force that can be generated due to the weight of an attached model cell, i.e. half sphere with diameter of $10 \mu \mathrm{m}$ and a density $1.1 \times 10^{3} \mathrm{~kg} / \mathrm{m}^{3}$, is about $5 \mathrm{pN}$. This force is even reduced if we consider the cell immerged in e.g. water. The apparent weight would be only some $5 \%$ of this i.e. $0.25 \mathrm{pN}$ Simple Newtonian mechanics imply that $1 \mathrm{nN}$ or $125 \mathrm{pN}$ is equivalent to about 200 and 25 times the force resulting from unit gravity, respectively. The effect of gravity on, especially, non-professional gravisensing cells suggests the existence of a no straightforward linear relation between the magnitude of this force and its impact on cells.

Acknowledgements I want to thank Dr. Millie Hughes-Fulford and Dr. Karl Hasenstein for their valuable suggestions and critical review of the initial, more elaborate, manuscript (van Loon 2007b). This paper was possible with support from NWO-ALW via the Netherlands Institute for Space Research, SRON grant MG-057.

Open Access This article is distributed under the terms of the Creative Commons Attribution Noncommercial License which permits any noncommercial use, distribution, and reproduction in any medium, provided the original author(s) and source are credited. 


\section{References}

Albrecht-Buehler, G.: Possible mechanisms of indirect sensing by cells. ASGSB Bull. 4(2), 25-34 (1991)

Ashkin, A.: Optical trapping and manipulation of neutral particles using lasers. Proc. Natl. Acad. Sci. U.S.A. 94, 4853-4860 (1997)

Autret, L., Mechaly, I., Scamps, F., Valmier, J., Lory, P., Desmadryl, G.: The involvement of Cav3.2/ $1 \mathrm{H}$ T-type calcium channels in excitability of mouse embryonic primary vestibular neurones. J. Physiol. 567(Pt 1), 67-78 (2005)

Bacabac, R.G.: Microrheology of mechanosensitive bone cells. In: Bone cell mechanosensitivity and microgravity. Academic thesis, Free University Amsterdam, The Netherlands, January 24 (2006)

Bacabac, R.G., Smit, T.H., Mullender, M.G., Dijcks, S.J., van Loon, J.J., Klein-Nulend, J.: Nitric oxide production by bone cells is fluid shear stress rate dependent. Biochem. Biophys. Res. Commun. 315, 823-829 (2004)

Bacabac, R.G., Smit, T.H., van Loon, J.J., Doulabi, B.Z., Helder, M., Klein-Nulend, J.: Bone cell responses to high-frequency vibration stress: does the nucleus oscillate within the cytoplasm? FASEB J. 20(7), 858-864 (2006)

Balaban, N.Q., Schwarz, U.S., Riveline, D., Goichberg, P., Tzur, G., Sabanay, I., Mahalu, D., Safran, S., Bershadsky, A., Addadi, L., Geiger, B.: Force and focal adhesion assembly: a close relationship studied using elastic micropatterned substrates. Nat. Cell Biol. 3(5), 466-472 (2001)

Baneyx, G., Baugh, L., Vogel, V.: Coexisting conformations of fibronectin in cell culture imaged using fluorescence resonance energy transfer. Proc. Natl. Acad. Sci. U.S.A. 98(25), 14464-14468 (2001)

Berry, M.V., Geim, A.K.: Of flying frogs and levitrons. Eur. J. Phys. 18, 307-313 (1997)

Binnig, G., Quate, C.F., Gerber, C.: Atomic force microscopy. Phys. Rev. Lett. 56, 930-933 (1986)

Briegleb, W.: Ein Beitrag zur Frage physiologischer Schwerelosichkeit. In: Briegleb, W. (ed.) Deutsche Luft-und Raumfahrt Vorträge aus dem Institut fuer Flugmedizin gehalten auf dem VI Internationalen und XII Europaeischen Kongress fuer Luft-und Raumfahrtmedizin in Rom 1963 und dem XIII Internationalen Kongress fuer Luft-und Raumfahrtmedizin in Bublin 1964, pp. 37-42. DVL, Cologne (1965)

Briegleb, W.: Ein Modell fuer Schwerlosichkeits-Simulation an Mikroorganismen. Naturwissenschaften 54(7), 167 (1967)

Briegleb, W.: Some qualitative and quantitative aspects of the fast-rotating clinostat as a research tool. ASGSB Bull. 5, 2330 (1992)

Brillouet, C.: Biorack on Spacelab IML-1. In: Mattok, C. (ed.) SP-1162. ESA Publication Division ESTEC, Noordwijk, The Netherlands (1995)

Brinckmann, E. (ed.): Biology in Space and Life on Earth. Wiley, Weinheim, Germany (2007)

Brinckmann, E., Brillouet, C.: Biorack on Spacehab. In: Perry, M. (ed.) SP-1222. ESA Publication Division ESTEC, Noordwijk, The Netherlands (1999)

Brokaw, C.J.: Mechanical components of motor enzyme function. Biophys. J. 73(2), 938-951 (1997)

Brown, R.B., Klaus, D., Todd, P.: Effects of space flight, clinorotation, and centrifugation on the substrate utilization efficiency of E. coli. Microgravity Sci. Technol. 13(4), 24-29 (2002)

Burger, E.H., Klein-Nulend, J., Cowin, S.C.: Mechanotransduction in bone, molecular and cellular biology of bone. In:
Zaidi, M., Bittar, E.E., Adebanjo, O.A., Huan, C.L.H. (eds.) Advances in Organ Biology, pp. 123-136. JAI, Stamford, Connecticut, USA (1998)

Clément, G., Slenzka, K. (eds.): Fundamentals of Space Biology: Research on Cells, Animals, and Plants in Space. Springer, New York, USA (2006)

Cogoli, A. (ed.): Cell biology and biotechnology in space. Adv. Space Biology and Medicine. Elsevier (2002)

Cole, K.S.: Dynamic electrical characteristics of the squid axon membrane. Arch. Sci. Physiol. 3, 253-258 (1949)

Cowin, S.C., Moss-Salentijn, L., Moss, M.L.: Candidates for the mechanosensory system in bone. J. Biomech. Eng. 113, 191197 (1991)

Demets, R.: Biological experiments on Bion-8 and Bion-9. In: Burk, W.R. (ed.) SP-1190. ESA Publication Division ESTEC, Noordwijk, The Netherlands (1996)

Fitzgerald, J., Hughes-Fulford, M.: Gravitational loading of a simulated launch alters mRNA expression in osteoblasts. Exp. Cell Res. 228(1), 168-171 (1996)

Forgacs, G., Yook, S.H., Janmey, P.A., Jeong, H., Burd, C.G.: Role of the cytoskeleton in signaling networks. J. Cell Sci. 117(Pt 13), 2769-2775 (2004)

Galland, P., Finger, H., Wallacher, Y.: Gravitropism in Phycomyces: threshold determination on a clinostat centrifuge. J. Plant Physiol. 161(6), 733-739 (2004)

Galvanovskis, J., Sandblom, J.: Amplification of electromagnetic signals by ion channels. Biophys J. 73, 3056-3065 (1997)

Gaubert, F., Schmitt, D., Lapiere C., Bouillon, R. (eds.): Cell and molecular biology research in space. FASEB J. 13, S1-S178 (1999)

Geitmann, A.: Cytomechanical tools for plant gravity research. ASGSB Bull. 20(2), 31-42 (2007)

Georges, P.C., Wagner, O., Yeung, T., Janmey, P.A.: Biopolymer networks and cellular mechanosensing. ASGSB Bull. 17(2), 45-50 (2004)

Gilchrist, C.L., Witvoet-Braamb, S.W., Guilak, F., Setton, L.A.: Measurement of intracellular strain on deformable substrates with texture correlation. J. Biomech. 40(4), 786-794 (2007)

Goede, A.P.H., Brakenhoff, G.J., Woldringh, C.L., Aalders, J.W.G., Imhof, J.P., van Kralingen, P., Mels, W.A., Schreinenmakers, P., Zegers, A.: Confocal microscopy in microgravity research. Adv. Space Res. 12(1), 109-112 (1992)

Grandi, F., Sandal, M., Guarguaglini, G., Capriotti, E., Casadio, R., Samori, B.: Hierarchical mechanochemical switches in angiostatin. Chembiochem. 7(11), 1774-1782 (2006)

Greenwood, P.E., Ward, L.M., Russell, D.F., Neiman, A., Moss, F.: Stochastic resonance enhances the electrosensory information available to paddlefish for prey capture. Phys. Rev. Lett. 84(20), 4773-4776 (2000)

Guilak, F., Erickson, G.R., Ting-Beall, H.P.: The effects of osmotic stress on the viscoelastic and physical properties of articular chondrocytes. Biophys. J. 82, 720-727 (2002)

Häder, D.-P., Hemmersbach, R., Lebert, M.: Gravity and the behavior of unicellular organisms. Cambridge University Press, Cambridge (2006)

Han, Y., Cowin, S.C., Schaffler, M.B., Weinbaum, S.: Mechanotransduction and strain amplification in osteocyte cell processes. Proc. Natl. Acad. Sci. 101(47), 16689-16694 (2004)

Hänggi, P.: Stochastic resonance in biology. How noise can enhance detection of weak signals and help improve biological information processing. ChemPhysChem. 3, 285-290 (2002)

Hatton, J.P., Pooran, M., Li, C.F., Luzzio, C., Hughes-Fulford, M.: A short pulse of mechanical force induces gene expression and growth in MC3T3-E1 osteoblasts via an ERK 1/2 pathway. J. Bone Miner. Res. 18(1), 58-66 (2003) 
Hemmersbach, R., Haeder, D.-P.: Graviresponses of certain ciliates and flagellates. FASEB J. 13, S69-S75 (1999)

Hill, P.S.M.: Vibration and Animal Communication: A Review. BioOne 41(5), 1135-1142 (2001)

Huang, H., Kamm, R.D., Lee, R.T.: Cell mechanics and mechanotransduction: pathways, probes, and physiology. Cell Am. J. Physiol. Physiol. 287(1), C1-C11 (2004)

Hughes-Fulford, M.: Signal transduction and mechanical stress. Sci STKE. 249(RE12), 1-8 (2004)

Kamm, R.D., Kaazempur-Mofrad, M.R.: On the molecular basis for mechanotransduction. Mol. Biol. Cell 1(3), 201-209 (2004)

Kennedy, H.J., Crawford, A.C., Fettiplace, R.: Force generation by mammalian hair bundles supports a role in cochlear amplification. Nature 433, 880-883 (2005)

Kim, S.H., Choi, Y.R., Park, M.S., Shin, J.W., Park, K.D., Kim, S.J., Lee, J.W.: ERK 1/2 activation in enhanced osteogenesis of human mesenchymal stem cells in poly(lactic-glycolic acid) by cyclic hydrostatic pressure. J. Biomed. Mater. Res. A 80(4), 826-836 (2007)

Klaus, D.M.: Clinostats and bioreactors. ASGSB Bull. 14(2), 55$64(2001)$

Klein-Nulend, J., Veldhuijzen, J.P., van de Stadt, R.J., van Kampen, J., Kuijer, R., Burger, E.H.: Influence of Intermittent Compressive Force on Proteoglycan Content in Calcifying Growth Plate Cartilage in Vitro. J. Biol. Chem. 262(32), 15490-15495 (1987)

Kondepudi, D.K.: Detection of gravity through nonequilibrium mechanisms. ASGSB Bull. 4(2), 119-124 (1991)

Kuznetsov, O.A., Hasenstein, K.H.: Magnetophoretic induction of curvature in coleoptiles and hypocotyls. J. Exp. Bot. 48(316), 1951-1957 (1997)

Lemmon, C.A., Romer, L.H.: Biologic consequences of cellular traction forces. ASGSB Bull. 20(2), 19-30 (2007)

Loesberg, W.A., Walboomers, X.F., van Loon, J.J.W.A., Jansen, J.A.: The effect of combined hypergravity and microgrooved surface topography on the behaviour of fibroblasts. Cell Motil. Cytoskelet. 63, 384-394 (2006)

Loesberg, W.A., Walboomers, X.F., Bronkhorst, E.M., van Loon, J.J., Jansen, J.A.: The effect of combined simulated microgravity and microgrooved surface topography on fibroblasts. Cell Motil. Cytoskelet. 64(3), 174-185 (2007)

McConnaughey, W.B., Petersen, N.O.: Cell poker: an apparatus for stress-strain measurements on living cells. Rev. Sci. Instrum. 51(5), 575-580 (1980)

Mesland, D., Brillouet, C.: Biorack on Spacelab D-1. In: Longdon, N., David, V. (eds.): SP-1091. ESA Publication Division ESTEC, Noorwijk, The Netherlands (1987)

Mitchison, J.M., Swann, M.M.: The mechanical properties of the cell surface. I. The cell elastimeter. J. Exp. Biol. 443-462 (1954)

Molenaar, C., Wiesmeijer, K., Verwoerd, N.P., Khazen, S., Eils, R., Tanke, H.J., Dirks, R.W.: Visualizing telomere dynamics in living mammalian cells using PNA probes. EMBO J. 22(24), 6631-6641 (2003)

Moore, D., Cogoli, A.: Gravitational and space biology at the cellular level. In: Moore, D., Bie, P., Oser, H. (eds.): Biological and medical research in space: an overview of life sciences research in microgravity, pp. 1-106. Springer, Berlin (1996)

Murray, D.W., Rushton, N.: The effect of strain on bone cell prostaglandin E2 release: a new experimental method. Calcif. Tissue Int. 47(1), 35-39 (1990)

Osawa, M., Masuda, M., Kusano, K., Fujiwara, K.: Evidence for a role of platelet endothelial cell adhesion molecule- 1 in endothelial cell mechano signal transduction: is it a mechanoresponsive molecule? J. Cell Biol. 158(4), 773-785 (2002)

Papaseit, C., Pochon, N., Tabony, J.: Microtubule selforganization is gravity-dependent. Proc. Natl. Acad. Sci. 97(15), 8364-8368 (2000)

Peeters, E.A.G., Bouten, C.V.C., Oomens, C.W.J., Baaijens, F.P.T.: Monitoring the biomechanical response of individual muscle cells under compression: a new compression device. Med. Biol. Eng. Comp. 41(4), 498-503 (2003)

Piekarski, K., Munro, M.: Transport mechanism operating between blood supply and osteocytes in long bones. Nature 269, 80-82 (1977)

Pierson, D., Moss, F.: Detecting periodic unstable points in noisy chaotic and limit cycle attractors with applications to biology. Phys. Rev. Lett. 75(11), 2124-2127 (1995)

Pollard, E.C.: Theoretical studies on living systems in the absence of mechanical stress. J. Theor. Biol. 8, 113-123 (1965)

Poodt, P.W.G., Heijna, M.C.R., Tsukamoto, K., de Grip, W.J., Christianen, P.C.M., Maan, J.C., van Enckevort, W.J.P., Vlieg, E.: Suppression of convection using gradient magnetic fields during crystal growth of $\mathrm{NiSO}_{4} \cdot 6 \mathrm{H}_{2} \mathrm{O}$. Appl. Phys. Lett. 87, 214105 (2005)

Prendergast, P.J.: Computational modeling of cell and tissue mechanoresponsiveness. ASGSB Bull. 20(2), 43-50 (2007)

Sasaki, K., Koshioka, M., Misawa, H., Kitamura, N., Masuhara, H.: Optical trapping of a metal-particle and a water droplet by a scanning laser-beam. Appl. Phys. Lett. 60(7), 807-809 (1992)

Saxena, A., Jacobson, J., Yamanashi, W., Scherlag, B., Lamberth, J., Saxena, B.: A hypothetical mathematical construct explaining the mechanism of biological amplification in an experimental model utilizing picoTesla $(\mathrm{PT})$ electromagnetic fields. Med. Hypotheses 60(6), 821-839 (2003)

Schmid-Schoenbein, G.W., Fung, Y.C., Zweifach, B.W.: Vascular endothelium-leukocyte interaction; sticking shear force in venules. Circ. Res. 36(1), 173-184 (1975)

Searby, N.D., Steele, C.R., Globus, R.K.: Influence of increased mechanical loading by hypergravity on the microtubule cytoskeleton and prostaglandin E2 release in primary osteoblasts. Am. J. Physiol. Cell Physiol. 289, 148-158 (2005)

Sem, D.S., Yu, L., Coutts, S.M., Jack, R.: Object-oriented approach to drug design enabled by NMR SOLVE: First real-time structural tool for characterizing protein-ligand interactions. J. Cell Biochem. Suppl. 37, 99-105 (2001)

Smith, S.B., Finzi, L., Bustamante, C.: Direct mechanical measurements of the elasticity of single DNA molecules by using magnetic beads. Science 258, 1122-1126 (1992)

Sun, H.W., Li, C.J., Chen, H.Q., Lin, H.L., Lv, H.X., Zhang, Y., Zhang, M.: Involvement of integrins, MAPK, and NF-jB in regulation of the shear stress-induced MMP-9 expression in endothelial cells. Biochem. Biophys. Res. Commun. 353, 152-158 (2007)

Tabony, J.: Gravity dependence of microtuble self-organisation. Gravit. Space Biol. Bull. 17(2), 13-25 (2004)

Tanaka, S.M., Li, J., Duncan, R.L., Yokota, H., Burr, D.B., Turner, C.H.: Effects of broad frequency vibration on cultured osteoblasts. J. Biomech. 36(1), 73-80 (2003)

Thevenet, D., D'Ari, R., Bouloc, P.: The Signal experiment in Biorack: Escherichia coli in microgravity. J. Biotechnol. 47(2-3), 89-97 (1996)

Thoumine, O., Ott, A., Louvart, D.: Cell Motil. Cytoskel. 33, 276287 (1996)

Todd, P.: Gravity-dependent phenomena at the scale of the single cell. ASGSB Bull. 2, 95-113 (1989) 
Tseng, Y., Kole, T.P., Wirtz, D.: Micromechanical mapping of live cells by multiple-particle-tracking microrheology. Biophys. J. 83, 3162-3176 (2002)

Turing, A.M.: The chemical basis of morphogenesis. Philos. Trans. R. Soc. Part B 237, 37-72 (1952)

van Loon, J.J.W.A., van Hulst, N.F.: Atomic force microscopy as tool in cell biological research for ground based and in-flight studies. 'Life Odyssey' 7th Europ. Symp Life Sciences Res. in Space, Maastricht, The Netherlands, ESA-SRON, Noordwijk,The Netherlands 29 May - 2 June 1999

van Loon, J.J.W.A., Veldhuijzen, J.P., Kiss, J.Z., Wood, C., vd Ende, H., Guntemann, A., Jones, D., de Jong, H., Wubbels, R.: Microgravity research starts on the ground! Apparatuses for long term ground based hypo- and hypergravity studies. Proc. 2nd Europ. Symp. on the Utilisation of the International Space Station, ESA SP-433, pp. 415419. ESTEC, Noordwijk, The Netherlands. 16-18 Nov 1998 (1999)

van Loon, J.J.W.A.: Some history and use of the Random Positioning Machine, RPM, in gravity related research. Adv. Space Res. 39,1161-1165 (2007a) van Loon, J.J.W.A.: Microgravity and mechanomics. Gravit. Space Biol. 20(2), 3-18 (2007b)

van Loon, J.J.W.A.: The gravity environment in space experiments. In: Breickman, E. (ed.) Biology in Space and Life on Earth, pp. 17-32 (2007c)

van Loon, J.J.W.A., van Laar, M.C., Korterik, J.P., Segerink, F.B., Wubbels, R.J., de Jong, H.A.A., Van Hulst, N.F.: An atomic force microscope operating at hypergravity for in situ measurement of cellular. Mechano-Response. (2008, Submitted).

Veldhuijzen, J.P., Bourret, L.A., Rodan, G.A.: In vitro studies of the effect of intermittent compressive forces on cartilage cell proliferation. J. Cell Physiol. 98(2), 299-306 (1979)

Wang, N., Butler, J.P., Ingber, D.E.: Mechanotransduction across the cell surface and through the cytoskeleton. Science 260(5111), 1124-1127 (1993)

Went, F.W.: Am. Sci. 56, 400-413 (1968)

Xiang, S., Kim, E.Y., Connelly, J.J., Kirsch, N.N.J., Winking, J., Schwarz, G., Schindelin, H.: The crystal structure of Cdc42 in complex with collybistin II, a Gephyrin-interacting guanine nucleotide exchange factor. J. Mol. Biol. 359, 35-46 (2006) 